\title{
Economic Policy as a Determinant of Development and More Efficient Business Operation in the Republic of Srpska
}

\author{
Zoran Mastilo $^{1}$ \\ ${ }^{1}$ University of East Sarajevo, Bosnia and Herzegovina \\ Correspondence: Zoran Mastilo, University of East Sarajevo, Bosnia and Herzegovina.
}

Received: November 7, 2016 Accepted: November 28, 2016 Online Published: November 29, 2016

doi:10.11114/bms.v2i4.2027

URL: http://dx.doi.org/10.11114/bms.v2i4.2027

\begin{abstract}
The Republic of Srpska needs a developing economic policy in order to make it a key determinant of more efficient business operation. The present economic policy is far from being like that, as it is more recession like given that it does not determine development yet. The economic policy of the Republic of Srpska has failed to perform its function years and especially for the incoming 2016, when, in addition to previous scope of welfare, which was defined as a target, it set to itself an additional goal to also finance pensions from the Budget in the coming period. The RS Government has gone even further and has even praised in public that in 2017 the Public Health Service would also be financed from the Budget, which will most certainly place an additional burden to an already strained Budget of the Republic of Srpska, whose 1/5 has been regularly replenished by using resources of International Monetary Fund. The Republic of Srpska, unlike many other countries worldwide, has abandoned Bismarck social insurance system and has adopted the Beverage system which is rarely applied worldwide. Such occurrence appears only when an economic system of a parent state cannot finance social rights out of its operations. Unfortunately, it has happened to the Republic of Srpska. Thus defined objectives and economic policy created in this way would not provide any positive growth rate, higher employment level, abatement of public debts nor cutting the deficit in any country, let alone in the RS. The said arguments will additionally contribute to poor living standard of citizens i.e. the citizens would experience even worse conditions than today, while only a small number of them would live in abundance. Such poor condition was not only caused by the global economic and financial crisis, but the culprits should be sought among those who have poorly planned, managed and spent scarce financial resources of the RS. Economic policy of the Republic of Srpska should spawn certain indicators, which would become a determinant of development and better business operation. It would considerably benefit to greater wealth of the Republic of Srpska and provide better living standard of its citizens.
\end{abstract}

Keywords: economic policy, economic development, unemployment, employment, determinants, wealth, social welfare policy

\section{Introduction}

The economic system and economic policy are built based on the knowledge and skills of individual schools of economic and political thought, known as Neoclassical (or Neoliberal) School, Keynesian school, Radical Political Economy, Marxist School, Institutionalism, etc. Depending on specific political and economic situations, a School is suitable to a country, social group, class or political group or a coalition. Simultaneously, it may not be suitable to the other, social or class group, political coalition and the government formed by it (Mastilo \& Simić, 2014). Economic policy of the Republic of Srpska is a document which defines the objectives of economic policy and the basics of sectorial policy of the Government in 2016. It analyses macroeconomic developments in the international environment and in the Republic of Srpska, and their integration or mutual influence, provides projections of macroeconomic indicators for the upcoming period. The adopted economic policy of each country should be accompanied by an action plan for its implementation, which clearly defines all the activities, bearers and deadlines for such implementation.

The Global economic and financial crisis has also brought its negative effects to small economies such as Bosnia and Herzegovina and its entities. Many macroeconomic indicators in the RS (GDP growth rate, unemployment, public debt and deficit) are unfavourable, suggesting that the economic policy of RS lacks its development component, but whose social/welfare component becomes increasingly more highlighted on a daily basis, in order to maintain social order and peace in the RS. Such statement is confirmed by the predefined goals of the economic policy of RS for 2016, where in 
addition to all the social benefits, one of the key objectives is the financing of Pension Fund from the state budget in order to cover the outstanding amount (gap funding). The funds outstanding for disbursement of pensions on a monthly basis amount to 20000000 BAM. However, the cumulative deficit of the Fund from as of 31 December 2015 amounts to $250000000 \mathrm{BAM}$. Therefore, the entire society will suffer, jeopardising the future budget of the Republic of Srpska and endangering its sustainability. The Government of the Republic of Srpska has publicly boasted that the priority in the disbursement of funds from the Budget shall be granted to the people with the pension rights and that they would be a priority group in the Republic of Srpska, thus placing them before the government incentives and investments for the crippled economy as well as before stimulation of export, which will negatively affect the much-needed development of the Republic of Srpska.

The key global issue is unemployment, with modern economic policy trying to find a way to facilitate this plague as its complete elimination is not possible. Nowadays, every tenth citizen in Europe is unemployed. Thus, according to Eurostat data, the unemployment rate in the Eurozone reached a new record of $12.2 \%$ in April 2014, therefore directly stimulating the economic crisis, which becomes a threat to the social life of the European Union. Bosnia and Herzegovina and its entities are, unlike most other countries, faced with an extremely high unemployment rate. Thus, on 30 September 2015 a total unemployment rate of 540,886 or $43.9 \%$ of job seekers were registered in Bosnia and Herzegovina. The BIH unemployment rate recorded in 2013 amounted to 552,462 people seeking their first job, whereas the unemployment of highly educated personnel in $\mathrm{BiH}$ maintains increasing on a monthly rate. It is unlikely to expect that such economic policy will be the determinant of development and more efficient business operation in the Republic of Srpska, which is the title of this paper.

\section{Macroeconomic Developments}

\subsection{International Economic Environment}

According to the IMF report from October 2015, World Economic Outlook (WEO) which analyses global economic trends, projections for global growth amount to 3.1\%. A weaker recovery in 2015 and 2016 (compared to earlier projections) is mainly the result of the impact of global factors (high public and private debt, weakness of the financial sector, low level of investment, low growth rate of labour productivity, demographic transitions, drop in raw material prices, etc.), which also present risks to the realization of the projected growth. According to the same projections, the economic growth in the Eurozone (has) amounted to $1.5 \%$ in 2015 and $1.6 \%$ in 2016, while in the European Union it (has) amounted to $1.9 \%$ in 2015 and $2 \%$ in 2016. For European developing countries ${ }^{1}$ a growth of $3 \%$ in 2015 and 2016 was projected. According to the IMF, the region of Southeast Europe has benefited from lower oil prices and a gradual recovery of the Eurozone, but on the other hand, was affected by the situation in Russia and by its high corporate debt.

Table 1. Overview of IMF projections, updated in October 2015

\begin{tabular}{|c|c|c|c|c|}
\hline Real GDP growth, $\%$ & 2013 & 2014 & 2015 & 2016 \\
\hline World & 3.4 & 3.4 & 3.1 & 3.6 \\
\hline Developed countries & 1.4 & 1.8 & 2.0 & 2.2 \\
\hline Eurozone & -0.5 & 0.9 & 1.5 & 1.6 \\
\hline Developing countries & 5.0 & 4.6 & 4.0 & 4.5 \\
\hline The European Union & 0.1 & 1.5 & 1.9 & 1.9 \\
\hline European developing countries & 2.9 & 2.8 & 3.0 & 3.0 \\
\hline $\begin{array}{l}\text { World trade growth } \\
\text { (goods and services), \% }\end{array}$ & 3.5 & 3.3 & 3.2 & 4.1 \\
\hline $\begin{array}{l}\text { Oil price growth, in USD, } \\
\text { Annual change, } \%\end{array}$ & -0.9 & -7.5 & -46.4 & -2.4 \\
\hline Consumer prices & & & & \\
\hline Developed countries & 1.4 & 1.4 & 0.3 & 0.2 \\
\hline Developing Countries & 5.9 & 5.1 & 5.6 & 5.1 \\
\hline
\end{tabular}

Source: IMF, World Economic Outlook Update October 2015.

Similarly, according to projections of the European Commission from November $2015^{2}$, a slight economic recovery is expected to continue in the future, despite the many challenges in the global economy. Namely, despite the drop in oil prices and the weakening of the euro, the economic recovery in 2015 was present in almost every EU member state, but

\footnotetext{
${ }^{1}$ European developing countries include: Serbia, Croatia, Bulgaria, Hungary, Poland, Romania and Turkey, including Albania, Bosnia and Herzegovina, Kosovo, FYROM and Montenegro.

22015 Autumn Economic Forecast of the European Commission
} 
maintained relatively low intensity. The expected real GDP growth in the Eurozone amounted to $1.6 \%$ in 2015 and to $1.8 \%$ in 2016, while the expected growth in EU was $1.9 \%$ for 2015 and $2 \%$ for 2016 .

Table 2. European economic forecast for the EU, autumn 2015

\begin{tabular}{lllll}
\hline Forecast for EU & 2013 & 2014 & 2015 & 2016 \\
Real GDP growth (\%, y/y) & 0.2 & 1.4 & 1.9 & 2.0 \\
Inflation (\%, y/y) & 1.5 & 0.6 & 0.0 & 1.1 \\
Unemployment (\%) & 10.9 & 10.2 & 9.5 & 9.2 \\
Budget balance (\% GDP) & -3.3 & -3 & -2.5 & -2 \\
Total public debt (\% GDP) & 87.3 & 88.6 & 87.8 & 87.1 \\
Current account balance (\% GDP) & 1.5 & 1.6 & 2.2 & 2.2 \\
\hline
\end{tabular}

Source: European Commission, November 2015.

\subsection{Macroeconomic Developments in the Republic of Srpska}

Based on development of macroeconomic indicators of the Republic of Srpska in the previous and in the period between January-September 2015, with reference to the economic activities in the Republic of Srpska and neighbouring countries, the activities initiated and policies planned by the Government of the Republic of Srpska, the forecast of the development of Republic of Srpska's macroeconomic indicators was made for 2015 and 2016.

Table 3. Key macroeconomic indicators of RS (2010-2015)

\begin{tabular}{|c|c|c|c|c|c|c|}
\hline INDICATORS (year) & 2010 & 2011 & 2012 & 2013 & 2014 & 2015 \\
\hline $\begin{array}{l}\text { Population of RS } \\
\text { (estimate) }\end{array}$ & $1,433,038$ & $1,429,668$ & $1,429,290$ & $1,425,549$ & $1,421,310$ & $\mathrm{n} / \mathrm{a}$ \\
\hline $\begin{array}{l}\text { Nominal GDP } \\
\text { (in } 1,000 \text { BAM) }\end{array}$ & $8,308,120$ & $8,670,050$ & $8,594,153$ & $8,761,456$ & $8,823,628$ & $\mathrm{n} / \mathrm{a}$ \\
\hline Real growth rate & $0.8 \%$ & $0.8 \%$ & $-1.0 \%$ & $1.9 \%$ & $0.4 \%$ & $\mathrm{n} / \mathrm{a}$ \\
\hline Number of employed (September) & 247,388 & 237,923 & 238,836 & 240,305 & 243,102 & 245,975 \\
\hline Number of unemployed & 145,343 & 150,344 & 153,225 & 151,290 & 1472,675 & 139,465 \\
\hline Average Net salary ( in $\quad$ BAM ) & 784 & 809 & 818 & 808 & 825 & 831 \\
\hline Industrial production growth rate & $5.0 \%$ & $4.7 \%$ & $-4.20 \%$ & $4.1 \%$ & $0.7 \%$ & $2.7 \%$ \\
\hline Export ( in 1,000 BAM ) & $2,177,809$ & $2,561,928$ & $2,374,338$ & $2,588,104$ & $2,694,054$ & $2,513,206$ \\
\hline Import ( in 1,000 ) & $4,053,076$ & $4,584,193$ & $4,487,543$ & $4,551,601$ & $4,946,182$ & $4,296,086$ \\
\hline Trade balance (in 1,000 BAM ) & $-1,875267$ & $-2,022265$ & $-2,113205$ & $-1,963497$ & $-2,252128$ & $-1,782880$ \\
\hline Export-import ratio & $53.7 \%$ & $55.9 \%$ & $52,9 \%$ & $56.9 \%$ & $54.5 \%$ & $58.5 \%$ \\
\hline Inflation (consumer prices) & $2.5 \%$ & $3.9 \%$ & $2.1 \%$ & $0.0 \%$ & $-1.2 \%$ & $-1.6 \%$ \\
\hline
\end{tabular}

Source: Chamber of Commerce of RS

The Republic of Srpska was hit by floods twice in 2014 (in May and August). A real GDP growth amounted to $0.2 \%$. In addition to bad weather situation, economic trends were heavily influenced by the drop in oil and food prices at the world market, as well as by exit of the Eurozone out of recession. Real GDP growth rates in the first two quarters of 2015 amounted to $0.9 \%$ and $1.5 \%$, respectively, ${ }^{3}$ which was caused by the continuing deflationary pressures, the recovery of the Eurozone and the countries of the region and growth in the areas of industrial production and construction. It is important to stress that the volume of foreign trade in 2014 amounted to 7.6 billion, which, compared to the year before, was higher by $6.7 \%$, while the export-import ratio amounted to $54.4 \%$. Export growth was $3.4 \%$, while import growth was $8.5 \%$, which was mainly caused by the increase in exports and imports of the manufacturing industry, which in the overall export-import structure accounts for about $70 \%$ to $80 \%$. In the period January - September 2015 , the volume of foreign trade decreased by $7.1 \%$ as a result of reduced export by $4.1 \%$ and reduced import by $8.7 \%$, while the export-import ratio amounted to $58.9 \%$. Drop in export was greatly influenced by the decline of export in the areas of petroleum oils and oils obtained from bituminous minerals, other than crude $(-57.2 \%)$, electricity $(-45.7 \%)$ and firewood $(-20 \%)$ (EUROSTAT, 2015). The drop of imports was mainly influenced by drop in crude oil import from Russia (-33.7\%), which participates significantly in the structure of imports with $15.1 \%$ (5.7 per cent less than in the same period of 2014), thus influencing the movement of imports. It is estimated that the reduction of export on an annual basis shall amount to $2.9 \%$ and of import to $7.5 \%$.

\footnotetext{
3 The estimated data from the Republic Institute of Statistics of the Republic of Srpska.
} 


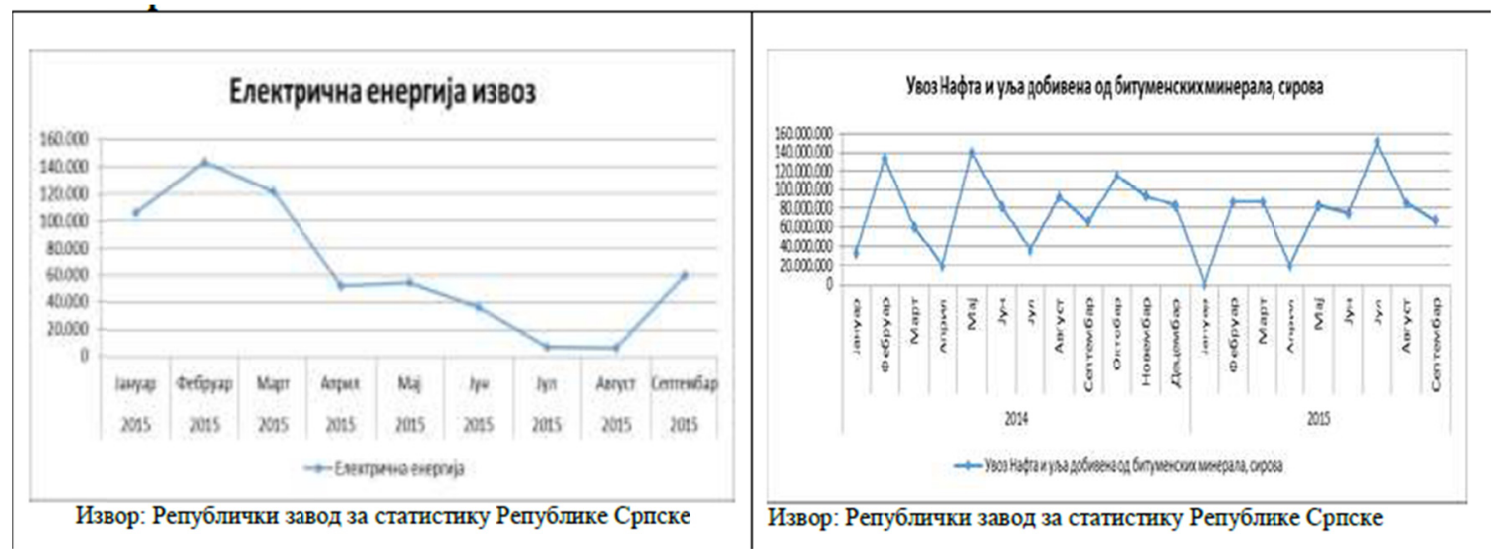

Figure 1. Trends in electricity exports and imports of crude oil in the period January - September 2015

Electricity export, Import: petroleum oils and oils obtained from bituminous minerals, raw

Source: the Republic Institute of Statistics of the Republic of Srpska,

Speaking of export of electricity, it may be encouraging that in 2016, Stanari Thermal Power Plant began operation, thus increasing the plan of electricity production by $27.8 \%$ compared to the planned production in 2015 . In addition, and in accordance with the forecasted improvement in economic activity in the major foreign trade partners of the Republic of Srpska and the expected growth in export demand, the forecasted growth rate of export in 2016 is $5 \%$, of import $4.4 \%$, while export-import ratio amounts to $57.4 \%$.

As far as the economic policy of the Republic of Srpska is concerned, a special attention should be paid to the Republic of Srpska's public debt, which includes domestic and external debt of the Republic, domestic (internal) and external debt of local governments, and domestic debt of social security funds and the University Clinical Centre of the Republic of Srpska (KBC) in Banja Luka. On 31 December 2014 the debt amounted to 4,090.6 million BAM, whereas the estimate for the end of 2015 is 4,357.4 million BAM. The total debt of the Republic of Srpska, which in addition to public debt includes external debt of public enterprises and Investment-Development Bank of the Republic of Srpska (IRB RS), amounted to 5,055.2 million BAM on 31 December 2014, while the estimate for the end of 2015, amounted to 5,351.4 million BAM. This represents a serious challenge for the Republic of Srpska, and, above all, imposes the question on how to manage the debt. Can the economic policy with such enormous public debt be a determinant of development of a more efficient business operation in the Republic of Srpska? The answer is - hardly, especially in 2016, when concerning the fact the government has normatively tasked the RS budget to cover the outstanding amounts of pensions from the budget of RS. It shall most certainly pose a problem during the budget disbursement of pension rights, when it is known that the funds outstanding on a monthly basis amount to approx. $25000000 \mathrm{BAM}$, and that the cumulative unfunded deficit of the Pension Fund to the moment of transition to co-financing from the budget amounted to $300000000 \mathrm{BAM}$. Such condition indicates that the development itself will not be a priority, that the incentives for more efficient business operations shall most certainly be scarce, whereby the economic policy of the Republic of Srpska should be a key determinant of such process.

Table 4. Total and public debt of the Republic of Srpska on 31 December 2014 and estimates for 2015

\begin{tabular}{|c|c|c|c|c|c|}
\hline Debt & \multicolumn{2}{|c|}{$\begin{array}{l}31 / 12 / 2014 \text { end } 2015 \\
\text { million BAM }\end{array}$} & \multirow{2}{*}{$\begin{array}{c}\text { Index } \\
109.7\end{array}$} & \multicolumn{2}{|c|}{$\begin{array}{l}31 / 12 / 2014 \text { end } 2015 \\
\% \text { of total debt }\end{array}$} \\
\hline 1. External debt & $2,887.2$ & 3.167 & & $57.1 \%$ & $59.2 \%$ \\
\hline Republic of Srpska (budget) & $1,859.1$ & $2,093.8$ & 112.6 & $36.80 \%$ & $39.10 \%$ \\
\hline Local government & 63.5 & 79.3 & 124.9 & $1.3 \%$ & $1.5 \%$ \\
\hline Public enterprises and IRB & 964.7 & 993.9 & 103 & $19.1 \%$ & $18.6 \%$ \\
\hline Domestic debt & 2.168 & $2,184.4$ & 100.8 & $42.9 \%$ & $40.8 \%$ \\
\hline of Republic of Srpska (budget) & 1.528 & $1,572.8$ & 102.9 & $30.2 \%$ & $29.4 \%$ \\
\hline Local government & 330.4 & 255.6 & 77.4 & $6.5 \%$ & $4.8 \%$ \\
\hline Social security funds and KBC & 309.7 & 356.0 & 114.9 & $6.1 \%$ & $6.7 \%$ \\
\hline Srpska (budget) $(1.1+2.1)$ & 3.387 & $3,666.6$ & 108.3 & $67.0 \%$ & 68.5 \\
\hline 4. Debt of Local government units $(1.2+2.2)$ & 393.8 & 334.9 & 85 & $7.8 \%$ & $6.3 \%$ \\
\hline 5. Debt of Social security funds and KBC (2.3) & 309.7 & 356 & 114.9 & $6.1 \%$ & $6.7 \%$ \\
\hline 6. Debt of public enterprises and IRB (1.3) & 964.7 & 993.9 & 103 & $19.1 \%$ & $18.6 \%$ \\
\hline 7. PUBLIC DEBT $(3+4+5)$ & $4,090.6$ & $4,357.4$ & 106.5 & $80.9 \%$ & $81.4 \%$ \\
\hline 8. TOTAL DEBT $(3+4+5+6)$ & $5,055.2$ & $5,351.4$ & 105.9 & $100 \%$ & $100 \%$ \\
\hline
\end{tabular}

Source: Ministry of Finance of the Republic of Srpska. 
Accordingly, the share of public debt in GDP at the end of 2015 would amount to $48.8 \%$ of GDP (Figure 2), while the total debt of the Republic of Srpska shall amount to $60 \%$ of GDP. ${ }^{4}$ If we would take a look at the items expected to experience significant increase of debt in 2015 compared to 2014, it is evident that one of the major items include the external debt of the Republic of Srpska (the Budget) and local government units, as well as the domestic (internal) debt of Social security funds. The increase of debt in 2015 is primarily a result of depreciation of BAM against other currencies and investment activities of the Republic of Srpska (rehabilitation of flood damages, investment in health and education sectors, housing refugees and displaced people, etc.). According to estimates of the Ministry of Finance of the Republic of Srpska, the share of public debt in GDP of the Republic of Srpska in 2016 will amount to 48.5\% of GDP.

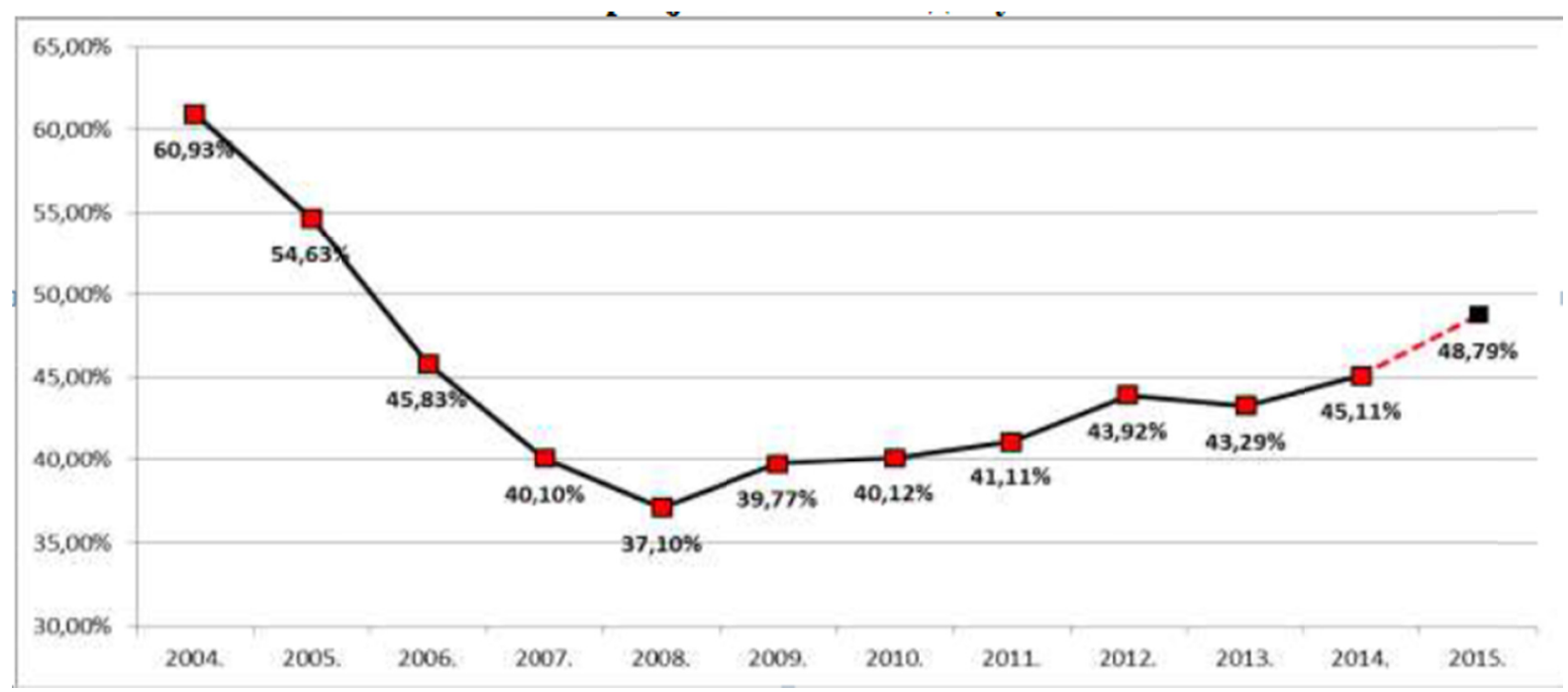

Figure 2. Public debt of the Republic of Srpska (\% of GDP) from 2004 to 2014 and estimate for 2015

Source: Economic Policy for 2016, p. 8

\section{The Areas Requiring Necessary Reform in the Republic of Srpska}

The main economic objectives of the Republic of Srpska should be identified and defined in its economic policy with an emphasis on stability, democracy and prosperity for all its citizens. The government needs to adopt an action plan that should be harmonized with the European Union and international financial institutions, for the purpose of implementing reforms, especially those most necessary ones that relate to the fundamental pillars of our society, such as:

economic growth, higher employment level, particularly employment of highly educated personnel, fiscal sustainability, social security, the rule of law, and European integration.

\subsection{Economic Growth}

A steady economic growth should be based on reforms in the following areas: Recovery of the economy and Improvement of the business climate and competitiveness.

Initiating the recovery process of the faltering economy aims to strengthen a more sustainable, more efficient, socially just and stable economic growth, to create new jobs, to increase and properly distribute social benefits, as well as to create a sustainable and equitable business environment. The recovery should be based on reducing the tax burden on labour, labour market reforms, infrastructure projects and reindustrialization of all manufacturing areas. Bearing in mind that the manufacturing industry is an important sector of the Republic of Srpska, the priority should be the commencement of re-industrialization process in all areas of the manufacturing industry which aims to start/revive production, increase the volume of industrial production and increase the employment levels.

\subsection{Higher Employment Level, Particularly of Highly Educated Personnel}

Unemployment is a global problem and a challenge for any government, particularly for the Government of RS. The economic theory and practical activities paid little attention to the unemployment issue, or at least not to an appropriate

${ }^{4}$ The estimates of indicators for public debt (48.8\% of GDP) and total debt (60.0\% of GDP) for 2014 do not include loans intended to finance the rehabilitation of the damages from the Unified Register of Damage - according to the Law on Borrowing, Debt and Guarantees of the Republic of Srpska ("Official Gazette of the Republic of Srpska", nos. 71/12 and 52/14) loans are excluded from the restrictions imposed on the total (60\%) and public debt of the Republic of Srpska (55\%). 
extent which unemployment by its nature, causes and consequences, requires in the cultural, economic, social and even political aspect.

Economic policymakers of EU countries have recognized that knowledge-based economy should be an imperative, which has been incorporated into the objectives set by the Lisbon Treaty, and is contained in the EU's growth strategy for the upcoming decade. The goals set are aimed at increasing employment, participation of highly educated personnel in the total population, invest in research and development. High unemployment level is one of the major economic and social problems in Bosnia and Herzegovina. One sixth of the working population in Bosnia and Herzegovina us unemployed, implying they are unable to care for themselves and their families. Bosnia and Herzegovina is a leading country in Europe in terms of unemployment. Speaking of such high unemployment level in Bosnia and Herzegovina, the fact of its longevity is particularly interesting - half of the unemployed people have been unemployed for five years or more, and only a fifth of the unemployed ones manage to find their first job within the period of one year. The facts suggest that $\mathrm{BiH}$ suffers not from cyclical, but from structural unemployment, with the chances of re-employment maintain declining on a daily basis. Bosnia and Herzegovina faces a total number of unemployed people of 540,886, or $43.9 \%$ of job seekers. There are 44,825 highly educated unemployed personnel in Bosnia and Herzegovina, thus making for about $8.28 \%$ of the overall unemployment structure of the country, followed by the 7,618 people with two-year post-secondary school qualifications persons or $1.41 \%$ of the unemployed ones. Such high level of unemployment has placed Bosnia and Herzegovina among the countries with the highest unemployment level in Europe, which also represents one of its greatest social and economic problems. This indicator is by itself sufficient to demonstrate that the negative consequences upon the economic system of $\mathrm{BiH}$ are substantial. High unemployment level in $\mathrm{BiH}$ is particularly high among highly educated people and maintains increasing on a yearly basis. Thus, in 2014 there were 44,825 or $8.28 \%$ of the unemployed people in $\mathrm{BiH}$, which is an increase of $7.9 \%$ compared to year 2013 , by $351.1 \%$ when compared to year $2008^{5}$. The core issue is the establishment of a connection of the education system with the labour market. It is necessary to undertake activities aimed at strengthening the process of internationalization of higher education, particularly by increasing the international mobility of students and academic staff.

\subsection{Fiscal Sustainability}

According to the Ministry of Finance, the debt of Republic of Srpska amounts to almost 50\% of its GDP. The European standards suggest that such indebtedness is not high, but considering the economic potential of a small economy such as the RS, it is clear that the aforementioned level is the upper limit of indebtedness. Therefore, what remains to be done in the coming period is a time-based restructuring of public and total debt in the medium and long term. The primary interest and effort should be that the annual instalments of repayment in the upcoming years are rescheduled by medium and long-term indebtedness under more favourable conditions in order to provide room to the budget to fund the development. Fiscal sustainability should be based on the following reform areas: Fiscal consolidation and Reform of the public sector.

\subsection{Social Security}

A successful social security should be provided through various policies, the most important ones being: Pension and Disability Insurance, Health and social care.

The occurrence that would most certainly place the economic policy of RS into pro-recession category is the fact that the Government has taken upon itself the gap funding (payment of outstanding pension entitlements) from the RS budget. Thereby, the Republic of Srpska, as few other countries abandoned the principle of intergenerational solidarity, i.e. the Bismarck model, and transcended to the payment of outstanding pension entitlements from the budget, which will certainly have a negative impact on development as the primary goal of any economy. In addition to this important pedestal of social security, the health system and reforms in that area are also of crucial importance for any other country.

\subsection{The Rule of Law}

The rule of law and the fight against organized crime and corruption represent the basic commitment of the Government of the Republic of Srpska in the field of judicial reform. The independence and impartiality of the courts are the bases for enforcing the rule of law, democracy and respect for human rights and freedoms. Judicial independence implies both the quality requirements of the judiciary system and the right of every citizen to place their rights and freedoms into the hands of independent judges.

\footnotetext{
${ }^{5}$ Labour and Employment Agency of Bosnia and Herzegovina, Report for year 2014.
} 


\subsection{European Integration}

European integration should be a priority commitment for the RS economy and, in this regard, it should be an imperative to upgrade and strengthen the institutional and human resource capacities for successful fulfilment of the EU accession process obligations and gradual alignment of the legislation of the Republic of Srpska with EU regulations.

\section{Discussion}

The economic policy of RS is increasingly becoming more inclined towards pro-recession and less towards development, thanks to the crisis and the accompanying constraints and limitations. These limitations include: zero rate of economic growth, abnormally high unemployment level, high public debt, high budget deficit, poor state of public finances and a different growth model based on domestic demand. Therefore, this kind of economic policy of RS must not be the determinant of development and more efficient business operation in the smaller entity of Bosnia and Herzegovina. The risks placed before the economic policy are not mitigated, nor are managed in any way. Quite the contrary, they maintain gaining momentum and additional presence even today. It would be unreasonable to expect in the coming period that the economic policy of the Republic of Srpska would be converted into a developmental one and become a determinant of development, considering the fact that the government has taken upon itself the gap funding (payment of outstanding pension entitlements) from the budget of RS. Therefore, social policy and resolution of social rights cannot be awarded a primary status in the order of payment from the budget, knowing that the welfare has always been funded from the development fund and increased fiscal power generated by the development. It would be unrealistic to expect that the ailing economy of RS would in due time become a determinant of development RS when it is known that it had been losing its power over a lengthy period and is faced with dismissal of workers. By creating and implementing appropriate strategies, through launching the reform of the economic system and encouraging economic activities through a variety of subsidies, primarily in the production field by stimulating export policy would certainly represent the measures through which it could be expected to spawn a significant improvement in the economic development of RS. Future economic policy should be aimed at encouraging the construction of sound economic institutions, primarily by conducting an economic policy which would take into account the programs of economic policy measures in times of crisis, which includes reinforcement of the economic sector, encouragement of domestic savings, export capacities and productivity. The said ideas should be supplemented with the implementation of necessary reforms in the social sector (Pension and Disability Insurance and Health Insurance), which would result in positive financial effects. The economic effects of reforms in the social/welfare sector, should provide stable funding of pension and health systems from the withholdings and contributions as anywhere else in the world, and not from the already overburdened RS budget. Objectives of economic policy should be focused on investing in the economy sector, primarily in the higher levels of product processing, with the aim of creating a new (final) product. Investments in the economy sector dealing with the higher level of product processing, aim to establish a newly created value, which will produce much-needed development in the Republic of Srpska. Such economic policy of RS would be a determinant of development and more efficient business operation in the smaller entity of Bosnia and Herzegovina.

\section{References}

Agency for Statistics of Bosnia and Herzegovina (2013). Women and Men in $\mathrm{BiH}$. http://www.bhas.ba/tematskibilteni/BHAS_Zene_Muskarci_BH.pdf

Agency for Statistics of Bosnia and Herzegovina (2014). Labour Force Survey 2014. http://www.bhas.ba/ankete/LFS_2014_001_01_bh.pdf

Aničić, J., Radović, D., \& Radović, V. (2013). Economic policy aimed at regional development, Ekonomski vidici, XVIII, 2-3.

Bošnjak, M. (January 2011). Global Economic and Financial Crisis and its Impact on the Economy, Survey for the

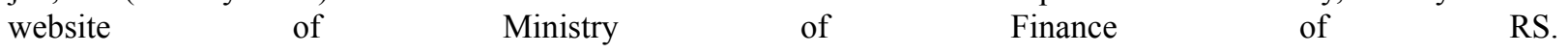
http://www.mfin.gov.rs/download/pdf/casopis_finansije/Casopis\%20Finansije\%201-6\%202008.pdf

Chamber of Commerce of the Republic of Srpska. Key macroeconomic indicators. http://komorars.ba/makroekonomija/

Dušanić, V. J. (2013). Criticism of Neoliberalism and Transition, Zagreb: Medinek.

Đukić, P. (1997). Power and Powerlessness of Economic Eolicy, Atlantida RS, Belgrade, 8.

Government of the Republic of Srpska, Newsletter of Economic Policy of the Republic of Srpska for 2016. http://www.vladars.net/sr-SP-Cyrl/Vlada/Ministarstva/mf/Documents/EkonomskapolitikaRSza2016.godinu_12034 425.pdf

Krstić, G., \& Šoškić, D. (2012). Economic Statistics, Publication Center, Faculty of Economics in Belgrade.

Mastilo, Z. (2013). Situation Analysis of Macroeconomic Aggregates in the RS and BiH in Terms of Sustainable 
Development, Annals from the Faculty of Economics in Subotica, 29.

Mastilo, Z. (2015). Analysis of Structural Unemployment of Highly Educated People in the Republic of Srpska and Measures on its Reduction. Economics, 4, 1-999. http://www.degruyter.com/view/j/eoik

Mastilo, Z. (2015). Risk Management in the Economic Policy of the Republic of Srpska in the Times of Crisis, , Journal for Economic Theory and Practice, 18, 51-57.

Mastilo, Z., \& Simić, S. (2014). The Role of Economic Policy in Stimulating the Growth and Development of the RS and BiH, Journal for Economic Theory and Analysis, 16(8), 42.

Mastilo, Z., \& Simić, S. (2014). Unemployment and Inflation, Proceedings JPD 2014, Faculty of Economics in Pale, 200-210.

Obadić, A., \& Majić, E. (2013). Analysis of the Unemployment Structure of Highly Educated People in the Republic of Croatia and the Measures for its Reduction, Business Excellence, 7-2, 103-122.

Polovina, S., \& Medić, Đ. (2002). Fundamentals of Economics, Zagreb: Medinek.

Stević, R. S. (2013). Analysis of GDP Structure of Bosnia and Herzegovina and Neighbouring Countries, Journal for Economic Theory and Practice, 14, 88-91.

Stojanov, D. (2013). Economic Crisis and the Crisis of Economic Science, Zagreb: Faculty of Economics in Rijeka.

This work is licensed under a Creative Commons Attribution 3.0 License. 